\title{
Erratum to: Sophono Alpha System and subtotal petrosectomy with external auditory canal blind sac closure
}

Giuseppe Magliulo $\cdot$ Rosaria Turchetta

Giannicola Iannella $\cdot$ Riccardo Valperga di Masino •

Marco de Vincentiis

Published online: 7 November 2014

(c) Springer-Verlag Berlin Heidelberg 2014

\section{Erratum to: Eur Arch Otorhinolaryngol}

DOI 10.1007/s00405-014-3123-2

The author would like to correct the surname of one of the co-authors in the original publication. The correct name should be Riccardo Valperga di Masino.

The online version of the original article can be found under doi:10.1007/s00405-014-3123-2.

G. Magliulo · R. Turchetta - G. Iannella · R. Valperga di Masino - M. de Vincentiis Organi di Senso Department, University "la Sapienza", Rome, Italy

R. Turchetta

e-mail: rosaria.turchetta@uniroma1.it

G. Iannella

e-mail: giannicolaiannella@ hotmail.it

R. Valperga di Masino

e-mail: valpyx@gmail.com

M. de Vincentiis

e-mail: marco.devincentiis@uniroma1.it

G. Magliulo $(\bowtie)$

Via Gregorio VII n. 80, 00165 Rome, Italy

e-mail: giuseppemagliuloorl@yahoo.com 